\title{
FAKTOR-FAKTOR PENYEBAB RENDAHNYA MINAT BACA SISWA
}

Oleh:

\author{
Asniar $^{1)}$, La Ode Muharam ${ }^{2)}$, Dodi Priyatmo Silondae ${ }^{3)}$ \\ 1) 2) 3) Jurusan Bimbingan dan Konseling \\ Fakultas Keguruan dan Ilmu Pendidikan, Universitas Halu Oleo \\ Email: asniar015@gmail.com
}

\begin{abstract}
ABSTRAK
Penelitian ini bertujuan untuk mengetahui faktor-faktor penyebab rendahnya minat baca siswa di SMA Negeri 1 Oheo. Jenis penelitian adalah penelitian kualitatif. Subjek dalam penelitian ini adalah guru mata pelajaran, guru bimbingan dan konseling, dan siswa SMA Negeri 1 Oheo. Teknik pengumpulan adalah observasi, wawancara dan studi dokumentasi. Metode analisis data menggunakan metode analisis deskriptif kualitatif model Miles dan Huberman. Hasil Penelitian adalah faktor penyebab rendahnya minat baca siswa di SMA Negeri 1 Oheo adalah faktor psikologi, faktor kebiasaan, faktor buku atau bahan bacaan, faktor lingkungan keluarga dan faktor lingkungan sekolah.
\end{abstract}

Kata Kunci: Minat Baca Siswa

\section{FACTORS AFFECTING STUDENTS LOW READING INTEREST IN SMA NEGERI 1 OHEO}

\begin{abstract}
The purpose of the research was to find out factors affecting students low reading interest in SMA Negeri 1 Oheo. This was qualitative research. The subjects of the research were subject teacher, guidance and counseling teacher, and the students of SMA Negeri 1 Oheo. The technique of data collection was observation, interview, and the study of documentation. The method of data analyses uses descriptive qualitative analyses through Miles Huberman model. The result of the study reveals that factors affecting students low interest in SMA Negeri 1 Oheo are as follows: psychology, habit, book or reading material, family environment, and school environment.
\end{abstract}

Keywords: Reading Interest. 


\section{Pendahuluan}

Membaca merupakan aktivitas belajar yang banyak dilakukan oleh manusia melalui buku, pamflet untuk mengetahui fenomena kondisi alam, kehidupan manusia dan lingkungan sekitarnya. Siregar (dalam Kasiyun, 2015) menjelaskan minat baca adalah keinginan atau kecenderungan hati yang tinggi (gairah) untuk membaca. Hal ini juga dikemukakan oleh Saepudin (2015:273) bahwa minat baca merupakan kecenderungan jiwa yang mendorong seseorang berbuat sesuatu terhadap membaca. Selanjutnya, Hurlock (dalam Hamzah \& Sofyan, 2015) mengemukakan minat baca merupakan sumber motivasi yang kuat bagi seseorang untuk menganalisa dan mengingat serta mengevaluasi bacaan yang telah dibacanya, yang merupakan pengalaman belajar menggembirakan dan akan memengaruhi bentuk serta intensitas seseorang dalam menentukan cita-citanya kelak di masa yang akan datang. Minat baca ditunjukkan dengan keinginan yang kuat untuk melakukan kegiatan membaca. Dengan membaca akan menjadikan sumber inspirasi, sumber pengetahuan siswa.

Minat baca siswa disebabkan oleh banyak faktor, seperti yang dikemukan oleh Soeatminah (dalam Idris \& Ramadani, 2015: 31) bahwa faktor penyebab rendahnya minat baca yaitu 1) faktor pembawaan atau bakat, faktor yang diturunkan oleh orang tua kepada anaknya, 2) faktor jenis kelamin, sifat dan kodrati maka wanita dan pria memiki minat dan selera yang berbeda, 3) faktor tingkat pendidikan, disebabkan karena perbedaan kemampuan keadaan dan kebutuhan, 4) faktor kesehatan, apabila seorang anak dalam keadaan kurang sehat maka gairahnya untuk membaca akan berkurang, 5) faktor keadaan jiwa, apabila seorang anak dalam keadaan resah sedih maka gairahnya untuk membaca akan hilang, 6) faktor kebiasaan, anak yang tidak memunyai minat baca akan menggunakan waktu luangnya untuk bermain, 7) faktor lingkungan keluarga, lingkungan keluarga yang punya kebiasaan dan kegemaran membaca akan memberikan pengaruh yang besar terhadap minat baca anak dan 8) faktor lingkungan sekolah.

Somadoyo (dalam Triatma, 2016) mengemukakan bahwa setiap aspek kehidupan melibatkan kegiatan membaca. Kegiatan membaca salah satu upaya untuk meningkatkan kecerdasan bangsa tidak selalu melalui pendidikan formal saja, akan tetapi dapat juga melalui jalur pendidikan non formal, diperlukan adanya sarana komunikasi informasi ilmu pengetahuan untuk disampaikan kepada masyarakat yaitu perpustakaan sekolah.

Pada kenyataannya, minat membaca masyarakat khusunya anak sebagai pelajar saat ini masih rendah. Hal ini dapat dilihat dari hasil survey pada tahun 2016 United Nasional Education Society and Cultural Organization (UNESCO) yang menemukan fakta minat baca masyarakat Indonesia betul-betul rendah, bahkan paling rendah di Asia. Berdasarkan data tersebut, diketahui bahwa minat baca masyarakat indonesia sangat rendah dibandingkan dengan negara-negara lainnya. Dari 61 Negara, Indonesia menduduki peringkat ke 60 minat baca paling rendah. Dilihat dari angka-angka dan data-data lain kemampuan membaca Indonesia dengan negara lain seperti negara ASEAN pun masih sangat jauh. Jika dibandingkan masyarakat Eropa atau Amerika khususnya anak-anak yang dalam setahun bisa membaca hingga $25-27 \%$ buku. Di negara Jepang minat bacanya masyarakatnya bisa mencapai 15 $18 \%$ buku pertahun. Sementara masyarakat Indonesia jumlahnya hanya mencapai $0,01 \%$ pertahun (tirto.id, 2018).

Rendahnya minat baca siswa dapat berpengaruh terhadap pendidikan sehingga berdampak pada kualitas kelulusan siswa, kurangnya pengetahuan, tidak memiliki kualitas diri dan tidak bisa memajukan peradaban sebab siswa tersebut tidak memiliki keinginan untuk membaca. Salah satu ciri-ciri anak yang tidak memiliki minat membaca yang tinggi (rendah), apabila ada waktu luang anak tersebut akan menggunakan waktu luangnya untuk kegiatan yang lain seperti bermain dan lain sebagainya (Soetminah dalam Meity \& Ramadani, 2015: 33).

Rendahnya minat baca siswa semakin banyak terjadi di sekolah-sekolah baik tingkat SD, SMP, SMA bahkan pada masyarakat umum. Rendahnya minat baca siswa di perpustakaan ini juga terjadi di salah satu sekolah di Kecamatan Oheo yaitu di SMA Negeri 1 Oheo. Berdasarkan informasi yang diperoleh dari hasil wawancara dengan guru bimbingan dan konseling di SMA Negeri 1 Oheo mengatakan bahwa banyak siswa yang memiliki minat baca yang rendah. Rendahnya minat baca siswa ditunjukkan dengan siswa yang kurang tertarik mengunjungi perpustakaan untuk membaca maupun meminjam buku. Sedikitnya siswa yang berkunjung di perpustakaan, rata-rata perhari kurang dari 15 siswa yang masuk di perpustakaan dari total 226 siswa di semua kelas. 
Informasi lain yang diperoleh adalah bahwa pada saat siswa diminta untuk membaca buku sebelum jam pelajaran dimulai siswa tidak antusias dalam membaca, siswa hanya membolak-balikan halaman buku. Siswa lebih memilih bercerita dengan temannya sehingga ketika diberikan pertanyaan terkait isi bacaan, siswa tidak mengetahui isi bacaan.

Kondisi rendahnya minat baca siswa tersebut dapat menyebabkan rendahnya kualitas diri siswa sebab dengan rendahnya minat baca, tidak bisa mengetahui perkembangan ilmu pengetahuan dan teknologi Indonesia. Jika rendahnya minat baca siswa di perpustakaan tidak mendapatkan penanganan dengan segera maka, siswa tidak akan memiliki wawasan yang luas.

Rendahnya minat baca siswa ini harus segera dihilangkan agar tidak membawa dampak yang buruk bagi siswa, untuk menghilangkan rendahnya minat baca siswa terlebih dahulu harus diketahui faktor-faktor penyebabnya agar nantinya dapat menghadirkan solusi yang tepat untuk permasalahan rendahnya minat baca siswa.

Berdasarkan uraian latar belakang permasalahan, peneliti mengangkat judul penelitian "Faktor-faktor Penyebab Rendahnya Minat Baca Siswa di SMA Negeri 1 Oheo". Penelitian ini bertujuan untuk mengetahui faktorfaktor penyebab rendahnya minat baca siswa di SMA Negeri 1 Oheo.

Rahim (2008: 28) mengemukakan minat baca merupakan keinginan yang kuat yang disertai usaha-usaha seseorang untuk membaca. Minat baca yang kuat diwujudkan dalam kesediaannya untuk mendapat bahan bacaan dan kemudian membacanya atas kesadaran sendiri tanpa adanya suatu paksaan sehingga diperoleh makna yang tepat menuju pemahaman yang dapat diukur. Senada dengan pendapat tersebut, Darmono (2014) juga mengemukakan minat baca merupakan kecenderungan jiwa yang mendorong seseorang berbuat sesuatu terhadap membaca. Orang yang memiliki minat baca yang tinggi senantiasa mengisi waktu luang dengan membaca. Orang yang demikian senantiasa haus terhadap bahan bacaan. Namun, bagi orang yang memiliki minat baca rendah, tidak akan mengisi waktu luang dengan membaca.

Lilawati (dalam Haryanti, 2015) juga mengemukakan bahwa minat baca merupakan suatu perhatian kuat dan mendalam yang disertai dengan Perasaan senang terhadap kegiatan membaca sehingga mengarahkan seseorang untuk membaca sesuai dengan kemauannya. Minat membaca dapat ditandai dengan adanya kesenangan membaca, kesadaran akan manfaat bacaan, frekuensi membaca dan jumlah buku bacaan yang pernah dibaca.

Dari beberapa pendapat tersebut, dapat disimpulkan bahwa minat baca merupakan suatu keinginan yang kuat dan mendalam disertai usahausaha yang mendorong seseorang untuk melakukan kegiatan membaca. Minat baca akan mengarahkan siswa untuk membaca atas kemauannya sendiri dan rasa senang yang timbul dari dalam dirinya.

Soeatminah (dalam Idris \& Ramadani, 2015:31) mengemukakan faktor-faktor yang memengaruhi minat baca adalah sebagai berikut:

1. Faktor Internal

a. Pembawaan atau bakat

Pembawaan atau bakat seseorang merupakan faktor genetik yang diturunkan oleh orang tua kepada anaknya. Jika kedua orang tuanya senang membaca buku akan kemungkinan sifat tersebut akan menurunkan pada anaknya. Apabila anak tersebut sudah memiliki rasa senang untuk membaca, berarti dia sudah memiliki kesadaran akan pentingnya membaca buku. Selain itu pembawaan atau bakat seorang anak memengaruhi rasa ketertarikan anak pada suatu bacaan.

b. Jenis kelamin

Perbedaan minat membaca juga dipengaruhi oleh perbedaan kelain. Mungkin karena sifat kodrati, maka pria dan wanita memiliki minat dan selera yang berbeda.

c. Keadaan kesehatan

Minat membaca seseorang akan dipengaruhi oleh keadaan kesehatannya. Apabila seorang anak membaca dalam keadaan yang kurang sehat/ sakit maka gairahnya untuk membaca akan terganggu bahkan minat bacanya bisa hilang.

d. Keadaan jiwa

Faktor kejiwaan seseorang juga berpengaruh terhadap minat bacanya. Apabila seorang anak yang memunyai minat membaca sedang dalam keadaan resah, sedih ataupun kacau pikirannya, maka gairah membacanya akan berkurang atau mungkin hilang.

e. Kebiasaan

Anak yang memunyai kebiasaan/ kegemaran membaca tentu memiliki minat terhadap buku/ bacaan, atau sebaliknya 
orang yang punya minat baca yang besar terhadap bacaan karena mereka telah memunyai kebiasaan dan gemar membaca. Anak yang gemar membaca dalam satu hari akan meluangkan waktu untuk membaca lebih banyak dari pada anak yang tidak suka membaca.

2. Faktor Eksternal

a. Buku atau bahan bacaan

Keragaman jenis buku juga mempengaruhi minat baca anak. Seorang anak berminat membaca sebuah buku bacaan atau buku apabila bacaan atau buku tersebut menarik, sesuai kebutuhan anak dan bermanfaat bagi anak tersebut.

b. Faktor lingkungan anak

1) Lingkungan keluarga

Lingkungan keluarga yang punya kebiasaan dan kegemaran membaca akan memberikan pengaruh yang besar terhadap minat baca anak.

2) Faktor lingkungan

Sekolah memiliki peran yang besar terhadap usaha menumbuhkan dan membina minat baca anak. Melalui bimbingan dan dorongan dari para pendidik (guru) siswa akan memunyai minat membaca. Misalnya, siswa akan lebih berminat membaca buku jika ia diberi tugas oleh gurunya untuk membaca sebuah buku. Ataupun sekolah menerapkan peraturan kepada siswanya untuk wajib membaca buku setiap hari, maka siswa dari sekolah tersebut akan memunyai minat baca yang lebih tinggi dari siswa sekolah lain. Kondisi perpustakaan yang ada di sekolah tersebut juga memengaruhi minat baca anak di perpustakaan sekolah.

\section{Metode Penelitian}

Penelitian ini telah dilaksanakan di SMA Negeri 1 Oheo, yang bertempat tinggal di Desa Walandawe. Penelitian ini dilakukan dalam kurun waktu selama satu (1) bulan.

Jenis penelitian ini adalah penelitian kualitatif dengan jenis studi kasus yang bertujuan untuk menggambarkan atau mengetahui secara mendalam mengenai faktor-faktor penyebab rendahnya minat baca siswa di SMA Negeri 1 Oheo.

Peneliti memeroleh informasi dengan melakukan metode wawancara, dimana peneliti melakukan wawancara dengan 1 guru Bimbingan dan Konseling, 1 guru mata pelajaran SMA Negeri 1 Oheo dan melanjutkan wawancara kepada 2 siswa.

Langkah-langkah analisis data kualitatif menurut Miles dan Huberman (dalam sugiyono, 2017: 133) penelitian ini adalah sebagai berikut:

1. Data collection (pengumpulan data)

Kegiatan pada setiap penelitian adalah mengumpulkan data dalam penelitian kuantitatif menggunakan kuesioner atau tes tertutup. Data yang diperoleh adalah data kualitatif. Data tersebut dianalisis dengan statistik dalam penelitian kualitatif pengumpulkan dengan observasi atau wawancara mendalam dan dokumentasi.

2. Data reduction (reduksi data)

Reduksi data merupakan proses pemilihan, pemusatan perhatian pada penyederhanaan, pengabsahan, dan transpormasi data "kasar" yang muncul dari catatan-catatan tertulis di lapangan. Tujuan penelitian dapat digunakan oleh peneliti sebagai acuan dalam mereduksi data sehingga data-data yang tidak sesuai dengan tujuan dapat direduksi. Dalam reduksi data merangkum pokok-pokok data yang diperoleh dari wawancara dan dokumentasi sehingga dapat memberikan gambaran yang jelas tentang faktor-faktor penyebab rendahnya minat baca siswa di SMA Negeri 1 Oheo.

3. Data display (penyajian data)

Penyajian data merupakan sekumpulan informasi tersusun yang memberi kemungkinan adanya penarikan kesimpulan dan pengambilan tindakan. Melalui penyajian data, data terorganisasi, tersusun dalam pola hubungan sehingga dapat semakin mudah dipahami. Penyajian data ditampilkan dengan sekelompok informasi yang memberi kemungkinan adanya penarikan kesimpulan dan pengambilan tindakan yang mengarah pada tercapainya sebuah tujuan penelitia

4. Data conclusion drawing/ verification (penarikan kesimpulan)

Kesimpulan dalam penelitian kualitatif diharapkan merupakan temuan baru yang dapat memberikan deskripsi atau gambaran suatu obyek yang sebelumnya masih remang-remang sehingga setelah diteliti menjadi jelas, dapat berupa hubungan kasual atau interaktif hipotesis atau teori. Kesimpulan yang dihasilkan dalam penelitian ini diarahkan untuk menjawab seluruh permasalahan penelitian dan 
memberikan gambaran tentang faktor-faktor penyebab rendahnya minat baca siswa di SMA Negeri 1 Oheo.

\section{Hasil Penelitian dan Pembahasan Hasil Penelitian}

Faktor-faktor penyebab rendahnya minat baca siswa di SMA Negeri 1 Oheo diuraikan secara rinci sebagai berikut:

\section{Faktor internal}

a. Faktor psikologi

Faktor psikologi merupakan faktor yang menyebabkan rendahnya minat baca yang meliputih Perasaan dan pikiran yang terganggu sehingga timbul rasa malas.

Berdasarkan hasil wawancara kepada siswa, diketahui bahwa siswa tidak memiliki keinginan untuk membaca sebab pikirannya sedang terganggu atau suasana hati yang tidak menyenangkan yang disebabkan oleh banyaknya masalah-masalah yang dialami ketika pikirannya sedang terganggu maka timbul rasa malas sehingga siswa tidak memiliki kemauan untuk membaca.

Penjelasan di atas dikemukakan oleh guru bimbingan dan konseling yang mengemukakan bahwa faktor keadaan jiwa yang menyebabkan sehingga minat baca mereka rendah yaitu faktor malas, kebanyakan siswa seperti ini dan rata-rata terjadi di semua kelas.

Berdasarkan penjelasan tersebut dapat disimpulkan bahwa faktor faktor keadaan jiwa dapat disebut penyebab rendahya minat baca siswa karena pikiran terganggu sehingga timbul rasa malas dalam diri siswa.

b. Faktor kebiasaan

Faktor kebiasaan merupakan faktor yang merujuk pada kebiasaan-kebiasaan yang sering dilakukan oleh siswa yaitu siswa tidak memanfaatkan waktu luang untuk membaca dan siswa akan membaca atas perinta guru.

Berdasarkan hasil yang diperoleh dari informan bahwa etika jam istrahat atau pada saat jam pelajaran kosong siswa lebih suka memanfaatkan waktu luangnya hanya untuk bermain jajan di kantin dan cerita bersama teman-teman dan siswa akan membaca ketika diperintah oleh guru.

Penjelasan di atas juga dikemukakan oleh guru bimbingan dan konseling dan guru mata pelajaran bahwa ketika siswa memiliki waktu luang kebiasaan mereka itu olahraga, makan, menggosip bersama teman dan sedikit untuk membaca.

Berdasarkan penjelasan tersebut dapat disimpulkan bahwa faktor kebiasaan dapat disebut faktor penyebab rendahnya minat baca siswa karena kebiasaan siswa yang kurang memanfaatkan waktu luang untuk membaca.

\section{Faktor eksternal}

a. Faktor buku atau bahan bacaan

Buku atau bahan bacaan menjadi faktor eksternal penyebab rendahnya minat baca siswa, siswa cenderung membaca buku atau bahan bacaan yang sesuai dengan keinginan mereka. Ketersediaan buku atau bahan bacaan masih sangat kurang dan tidak menarik untuk dibaca, siswa juga tidak memiliki koleksi buku atau bahan bacaan yang ia miliki.

Berdasarkan hasil wawancara yang diperoleh dari informan yang mengemukakan bahwa buku atau bahan bacaan yang ada di sekolah belum tersedia yang ada hanya buku yang berkaitan dengan mata pelajaran tetapi tidak lengkap.

Penjelasan di atas juga dikemukakan oleh guru mata pelajaran bahwa buku-buku/ bahan bacaan yang ada belum lengkap yang tersedia hanya buku yang berkaitan dengan mata pelajaran kalau buku yang lain seperti buku cerita, dongeng daan lain-lain belum tersedia dan jumlahnya masih sangat kurang.

Berdasarkan penjelasan tersebut dapat disimpulkan bahwa faktor buku atau bahan bacaan disebut faktor penyebab rendahnya minat baca siswa karena buku-buku yang ada di sekolah belum lengkap dan tidak sesuai dengan kebutuhan siswa.

b. Faktor lingkungan keluarga

Keluarga merupakan sumber utama atau lingkungan yang utama penyebab rendahnya minat baca siswa. Hal ini dapat dilihat dari kebiasaan membaca di lingkungan keluarga yang masih rendah, kurangnya perhatian yang diberikan pada orang tua terhadap anak seperti, orang tua jarang mengajak anak ke toko buku atau menyediakan buku-buku bacaan terhadap anak.

Berdasarkan hasil wawancara kepada siswa yang mengemukakan bahwa kebiasaan membaca di lingkungan keluarga 
masih rendah ini terjadi karena orang tua terlalu sibuk bekerja sehingga keluarga masih jarang membaca buku atau bahan bacaan serta kurangnya perhatian yang berikan pada orang tua pada anaknya.

Penjelasan di atas juga di kemukakan oleh guru bimbingan dan konseling bahwa kebiasaan membaca di lingkungan keluarga masih kurang, karena orang tua terlalu sibuk untuk bekerja serta kurangnya perhatian yang diberikan pada anak dan kurang motivasi dalam diri siswa, rata-rata siswa tidak memiliki kesadaran akan pentingnya membaca sehingga mereka menganggap bahwa membaca hanyalah hal yang biasa, orang tua juga sama seperti itu salah satu buktinya yaitu kurangnya perhatian orang tua siswa mereka tidak memerhatikan minat baca pada anaknya.

Berdasarkan penjelasan tersebut, dapat disimpulkan bahwa faktor lingkungan keluarga dapat disebut sebagai penyebab rendahnya minat baca siswa karena keluarga kurang memberikan perhatian dan motivasi pada minat baca anak.

c. Faktor lingkungan sekolah

Salah satu faktor penyebab rendahnya minat baca yaitu lingkungan sekolah. Lingkungan sekolah kurang mendukung minat baca siswa. Hal ini diketahui dari perpustakaan sekolah yang kurang mendukung seperti buku-buku yang ada di perpustakaan belum memadai, tata ruang perpustakaan tidak teratur dan tidak nyaman bagi siswa sehingga siswa tidak memiliki minat untuk berkunjung ke perpustakaan.

Berdasarkan hasil wawancara yang diperoleh dari siswa bahwa siswa tidak suka membaca karena perpustakaan sekolah, buku-bukunya belum lengkap, ruangan yang tidak teratur.

Penjelasan di atas juga dikemukakan guru Bimbingan dan Konseling bahwa faktor penyebabnya yaitu koleksi buku yang ada di perpustakaan belum lengkap, tidak ada jaringan internet karena ini merupakan salah satu kebutuhan yang dibutuhkan dan siswa kurang akan pengetahuan yang ia miliki.

Pernyataan tersebut juga dikemukakan oleh guru mata pelajaran bahwa faktor penyebabnya ada dua faktor yang pertama perpustakaan, seperti seperti meja baca, kursi dan lain lain tidak tertata dengan baik, koleksi buku belum lengkap dan yang kedua tidak ada jaringan internet jadi sulit untuk membaca.

Berdasarkan penjelasan tersebut dapat disimpulkan bahwa faktor lingkungan sekolah dapat disebut sebagai penyebab rendahnya mint baca siswa karena perpustakaan sekolah belum memadai dan buku-buku yang ada di sekolah belum lengkap.

\section{Pembahasan}

Faktor internal menyebabkan rendahnya minat baca siswa di SMA Negeri 1 Oheo yang pertama faktor yaitu faktor faktor keadaan jiwa. Faktor internal yang pertama menyebabkan rendahnya minat siswa adalah psikologi yang meliputi perasaan dan pikiran siswa yang terganggu karena siswa terlalu banyak memikirkan masalahnya yang dialami baik masalah pelajaran, pribadi dan lain sebagainya sehingga masalahmasalah siswa tersebut mengganggu suasana hatinya untuk membaca sehingga timbul sifat malas. Sifat malas merupakan salah satu sifat buruk yang terdapat pada diri seseorang yang menghambat kemajuan anak-anak maupun dewasa untuk membaca dan belajar untuk menambah ilmu pengetahuan. Sifat malas tersebut muncul secara tiba-tiba atau sudah menjadi kebiasaan seorang pelajar yang malas untuk membaca.

Faktor internal yang kedua yaitu faktor kebiasaan. Faktor kebiasaan yaitu kebiasan yang sering dilakukan oleh siswa seperti, siswa tidak memanfaatkan waktu luang untuk membaca, siswa hanya membaca atas perintah guru. Siswa tidak memanfaatkan waktu luang yang ada untuk membaca buku/ bahan bacaan baik di kelas maupun di perpustakaan seperti pada saat jam mata pelajaran kosong, jam istrahat. Siswa lebih cenderung meluangkan waktunya untuk bermain, bercerita dengan teman dan jajan di kantin dari pada membaca. Membaca belum menjadi aktivitas yang menarik untuk siswa lakukan pada waktu luangnya. Kurangnya kebiasaan siswa ini terjadi karena dalam diri siswa belum memunyai kesadaran tentang pentingnya membaca buku. Siswa akan membaca buku ketika diperintah oleh guru, siswa kurang memiliki inisiatif untuk membaca buku/ bahan bacaan atas kesadarannya sendiri.

Kemudian, faktor berikutnya yang menyebabkan rendahnya minat baca siswa yaitu 
faktor eksternal yang pertama faktor buku/ bahan bacaan. Ketersediaan buku atau bahan bacaan yang dibutuhkan siswa terbatas dan menarik minat siswa masih kurang dan siswa tidak memiliki koleksi buku atau bahan bacaan. Rata-rata siswa tidak memiliki koleksi buku atau bahan bacaan ini disebabkan oleh keterbatasan dari pihak sekolah dan keluarga dalam menyediakaan buku atau bahan bacaan yang dibutuhkan siswa. Perpustakaan sekolah memang menyediakan buku atau bahan bacaan tetapi masih kurang.

Faktor eksternal yang kedua yaitu faktor lingkungan keluarga. Faktor lingkungan keluarga dimana sebagian besar orang tua lebih sibuk dengan mengurus pekerjaannya sehingga anakanak tersebut kurang mendapat perhatian dari orang tua serta budaya membaca di lingkungan keluarga yang masih rendah, orang tua juga jarang membelikan buku atau mengajak ke toko buku. Selain itu latar belakang orang tua siswa yang masih belum memiliki kesadaran tentang pentingnya membaca.

Keluarga menjadi peranan penting dalam tumbuhnya minat membaca buku pada setiap anak terutama orang tua juga harus mendidik agar membaca menjadi kebiasaan bagi setiap anak. Terciptanya kebiasaan membaca dan kemampuan keluarga untuk membeli buku-buku dapat mendorong anak agar memiliki kemauan untuk membaca

Hasil penelitian ini jika dikaitkan dengan pendapat Sandjaja (dalam Aida, 2015: 117) menulis bahwa keluarga merupakan lingkungan awal dan dominan dalam menanamkan, menumbuhkan dan membina minat membaca anak. Orang tua perlu menanamkan kesadaran akan pentingnya membaca dalam kehidupan anak, setelah itu baru guru di sekolah, teman sebaya dan masyarakat.

Orang tua memberikan dukungan besar pada keadaan ini. Pola asuh orang tua kepada anak merupakan faktor penentu minat baca. Secara general, orang tua dengan tingkat pendidikan dan ekonomi yang kurang baik, berpotensi besar membuat minat baca anak rendah (Khairudin (dalam Maharani dkk, 2017: 326).

Lingkungan keluarga dapat menjadi faktor pendorong timbulnya minat baca rendah pada siswa karena orang tua tidak menyediakan beberapa bahan bacaan atau berbagai bahan bacaan dalam lingkungan lingkungan keluarga sehingga siswa tidak merangsang daya visual dan motoris siswa untuk sekedar membaca.
Faktor eksternal yang ketiga yaitu faktor lingkungan sekolah. Faktor lingkungan sekolah menjadi penyebab masalah rendahnya minat baca pada siswa dimana lingkungan sekolah ini kurang mendukung minat baca siswa seperti perpustakaan sekolah yang tidak memadai, buku-buku yang tidak lengkap, tidak ada jaringan internet untuk mengakses bahan yang akan dibaca

Perpustakaan sekolah merupakan salah satu fasilitas yang berguna untuk mendukung keberhasilan proses pembelajaran dan menumbuhkan minat baca siswa. Hal tersebut sulit tercapai apabila peran perpustakaan yang belum maksimal yaitu kondisi perpustakaan yang dimiliki sekolah, tata ruang perpustakaan tidak teratur dan tidak nyaman dan perlengkapan perpustakaan seperti meja baca, kursi dan lain lain tidak tertata dengan baik hal ini karena petugas perpustakaan disibukan dengan kegiatannya sehingga kurang memunyai waktu untuk merawat tata ruang perpustakaan. Masalah kondisi perpustakaan, tata ruang yang yang tidak nyaman membuat siswa tidak ingin mengujungi perpustakaan sekolah karena ketidakanyamanan yang ada di perpustakaan tersebut. Hampir semua jenis dan jenjang pendidikan, kondisi perpustakaan masih belum memenuhi standar sarana pendidikan. Perpustakaan belum sepenuhnya berfungsi jumlah buku buku-buku perpustakaan jauh dari mencukupi kebutuhan tuntunan membaca sebagai basis pendidikan serta peralatan yang tidak sesuai dengan kebutuhan.

\section{Kesimpulan dan Saran Kesimpulan}

Berdasarkan hasil penelitian dan pembahasan dapat disimpulkan bahwa faktorfaktor penyebab rendahnya minat baca siswa di SMA Negeri 1 Oheo yaitu faktor internal yang terdiri dari: 1) faktor psikologi, 2) faktor kebiasaan, serta faktor eksernal yang terdiri dari 1) faktor buku atau bahan bacaan, 2) faktor lingkungan keluarga dan faktor 3) lingkungan sekolah.

\section{Saran}

1. Bagi kepala sekolah, agar berupaya menyediakan fasilitas perpustakaan sekolah seperti buku-buku yang sesuai dengan kebutuhan siswa dan membuat perpustakaan menjadi nyaman.

2. Bagi guru BK, diharapkan agar menjalin kolaborasi dengan guru mata mata pelajaran, 
kepala sekolah dan orang tua siswa dalam meningkatkan minat baca siswa.

3. Bagi keluarga, diharapkan agar menanamkan budaya membaca di rumah, memfasilitasi kebutuhan pada anak dan hendaknya bisa memerhatikan anak serta memberikan dukungan atau motivasi agar minat siswa memiliki minat baca yang tinggi.

4. Bagi siswa, agar terbiasa membaca meskipun tanpa diperintahkan oleh guru atau orang lain karena membaca dapat memerluas wawasan pengetahuan.

\section{Daftar Pustaka}

Aida, Welven. (2015). Pengaruh Lingkungan Keluarga dan Minat Membaca Terhadap Hasil Belajar Ekonomi Siswa Kelas XI MU Pengetahuan sosial Sekolah Menengah Atas Negeri Kota Padang. Jurnal Ilmiah Cano Ekonomos. Vol. 4, No. 2, hh. 117.

Darmono. (2014). Manajemen dan Tata Kerja Perpustakaan Sekolah. Jakarta: PT Grasindo.

Hamzah, M \& A Sofyan Nst. (2015). Meningkatkan Motivasi Membaca. Jurnal Iqra. Vol. 9, No. 2, hh. 18.

Haryanti, Usmani. (2015). Pengaruh Layanan Konten Bimbingan dan Konseling Terhadap Perkembangan Minat Baca Siswa Kelas VII SMP Negeri 17 Surakarta Tahun Ajaran 2015/2016. Jurnal Ilmiah Konseling, BK FKIP UTP.Vol. 13, No. 2.

Idris, Meity, H. \& Izul Ramdani. (2015). Menumbuhkan Minat Membaca Pada Ana k Usia Dini. Jakarta Timur: Redaksi Umar.

Kasiyun, Suharmono. (2015). Upaya Meningkatkan Minat Baca Sebagai Sarana Untuk Mencerdaskan Bangsa. Jurnal Bahasa, Sastra, dan Pengajaran. Vol. 1, No. 1.

Maharani, Ony Dian, dkk. (2017). Minat Baca Anak-Anak Di Kampoeng Baca Kabupaten Jember. Jurnal Kajian Pendidikan dan Hasil Penelitian. Vol. 3, No. 1, hh. 326.
Rahim, Farida. (2008). Pengajaran Membaca di Sekolah Dasar. Jakarta: Sinar Grafi.

Saepudin, Encang. (2015). Tingkat Budaya Membaca Masyarakat. Jurnal Kajian Informasi \& Perpustakaan. Vol. 3. No. 2.

Sugiyono. (2017). Metode Penelitian Kuantitatif. Ed 3-Cet 1. Bandung: Alfabeta.

Tirto.com. (2017). Data Soal Rendahnya Minat Baca Indonesia. (online). http://google.co.id/amp.tirto.id/najwapaparan-data-soal-rendahnya-minat-bacaindonesia-cumM. Diakses pada tanggal 10 November 2018.

Triatma, Ilham Nur. (2016). Minat Baca Pada Siswa Kelas VI Sekolah Dasar Negeri Delegan 2 Prambanan Sleman Yogyakarta. Jurnal Prodi Teknologi Pendidikan. Vol. 5, No. 6, hh. 167. 